\title{
Pemanfaatan Metode Hill Climbing Mencari Lintasan Terpendek Objek Wisata Menggunakan sistem Informasi
}

\author{
Sestri Novia Rizki ${ }^{1}$, Yopy Mardiansyah ${ }^{2}$ \\ ${ }^{1}$ Teknik Komputer /Akademi Manajemen dan Informatika (AMIK) KOSGORO \\ Jl. RSDK No. 340 Koto Panjang Kota Solok, Sumatera Barat,e-mail: noviasestri@gmail.com \\ ${ }^{2}$ Teknik Industri/ Institut Teknologi Batam \\ JL.Kompleks Vitka Educity, Tiban Ayu, Batam, Kepulauan Riau,e-mail: yopi@iteba.ac.id
}

\begin{tabular}{|c|c|}
\hline ARTICLE INFO & ABSTRACK \\
\hline $\begin{array}{l}\text { Article history: } \\
\text { Received } 27 \text { Oktober } 2021 \\
\text { Received in revised form } 29 \text { Oktober } 2021 \\
\text { Accepted } 29 \text { Oktober } 2021 \\
\text { Available online } 1 \text { Desember } 2021\end{array}$ & $\begin{array}{l}\text { The search is often used to search for the shortest } \\
\text { route, the Hill Climbing Method is a part of the test } \\
\text { that uses heuristic functions. The problem that is } \\
\text { often encountered is in the form of miscalculations } \\
\text { in calculating the distance so that it requires long } \\
\text { distances, costs a lot and takes a very long time. To } \\
\text { solve this case, it can be solved by making a } \\
\text { structure graph by looking at the city points from the } \\
\text { two sides of the point to be passed. Using an } \\
\text { algorithm can help make it easier to find a location } \\
\text { and save time and travel costs that will be passed. } \\
\text { This advantage is that all points will be obtained } \\
\text { and checked from the right and left sides one by one } \\
\text { so as to obtain effective and maximum results. The } \\
\text { Hill Climbing method that will be used has the } \\
\text { concept of a geographic information system as a } \\
\text { guide and is used as a system for decision making. } \\
\text { The heuristic search method is one of the methods } \\
\text { commonly used in finding a way. }\end{array}$ \\
\hline
\end{tabular}

Keywords: Hill Cimbing method, graph, digital map. Geographic Information System

\begin{abstract}
Abstrak
Searching sering digunakan untuk pencarian dalam menghitung lintasan rute terpendek, Metode Hill Climbing meruapakan bagian pengujian yang menggunakan fungsi heuristik, Permasalahan yang sering dijumpai berupa salah perhitungan dalam menghitung jarak sehingga memerlukan jarak tempuh yang jauh,biaya yang banyak serta memerlukan waktu yang sangat lama. Untuk menyelesaikan kasus ini bisa di atasi dengan membuat struktur graph dengan milihat titik kota dari dua sisi titik jalur yang akan dilewati. Dengan menggunakan algoritma bisa membantu mempemudah menemukan lokasi dan menghemat waktu dan biaya perjalanan yang akan dilewati. Kelebihan algoritma ini adalah semua titik akan diperoleh dan diperiksa dari sisi kanan dan kiri satu persatu sehingga memperoleh hasil yang efektif dan maksimal. Metode Hill Climbing yang akan digunakan berkonsep kepada Sistim informasi geografis sebagai petunjuk arah dan dijadikan sebagai sistem dalam pengambilan keputusan. Metode pencarian heuristik merupakan salah satu metode yang umumnya digunakan dalam mencari lintasan
\end{abstract}

Kata kunci : Metode Hill Cimbing, grap, peta digital. Sistem Informasi Geografis

Received October 27, 2021; Revised October 29, 2021; Accepted October 29, 2021 


\section{PENDAHULUAN}

Solok merupakan kabupaten Kota madya yang Terletak di Propinsi Sumatra Barat, Letak kota solok berada pada ketinggian 329 meter sampai 1458 meter dari atas permukaan laut sehingga menjadikan kota solok memiliki suhu dingin serta pemandangan yang sangat indah, Selain itu Kota solok dijuluki sebagai kota yang menghasilkan beras yang sangat terkenal, Jarak tempuh solok dengan kota padang sekitar 40 Kilometer. Selain itu Kota Solok juga dikenal sebagai kota yang memiliki tempat wisata yang bagus dan sering dikunjungi oleh wisatawan, Permasalahan yang terjadi saat ini kurang nya petunjuk arah untuk mengunjungi tempat wisata yang ada dikota solok. Tujuan utama penelitian ini adalah membantu wisatawan dalam menentukan tempat wisata yang ada diKota Solok baik dari Jarak tempat rekreasi maupun waktu yang dibutuhkan untuk sampai di tempat lokasi wisata tersebut.

\section{TINJAUAN PUSTAKA}

Mengunjungi tempat wisata merupakan sebuah kebutuhan untuk menghilangkan kejenuhan setelah pikiran lelah dengan berbagai aktifitas. Jika tempat wisata tersebut belum pernah dikunjungi maka harus melakukan sebuah pencarian. Pencarian merupakan sebuah proses menelusuri solusi untuk suatu masalah sehingga menemukan tujuan, dengan kerja prinsip melakukan dari awal negara untuk menyelesaikan pencarian jalan ke memperoleh solusi atau keadaan tujuan [1]. Menurut para ahli lain, Pencarian adalah bagian dari kumpulan data yang sudah tersedia, istilah yang sering kita dengar sebagai table look-up atau menyimpan dan mengambil informasi. Dalam proses pencarian, kami sering menemukan kesalahan, sehingga kami membutuhkan proses yang benar dan menghasilkan output untuk dijadikan acuan. Metode pencarian bisa dibedakan menjadi 2 bagian, yaitu:

1. Pencarian buta / pencarian tanpa informasi (pencarian buta / tanpa informasi)

2. Pencarian heuristik / dengan informasi (heuristik atau pencarian informasi)

Pembahasan dalam jurnal ini menggunakan konsep pencarian heuristik dengan informasi sehingga memudahkan wisatawan. Dalam menyelesaikan metode pencarian, memiliki perbedaan karakteristik, dimana setiap metode memiliki kelebihan dan kekurangannya masing-masing. Untuk mendapatkan pencarian yang baik, ada empat hal yang harus dilalui antara lain:

a. Mendefinisikan Masalah dengan Benar

b. Definisi yang benar dari keadaan awal dan solusi yang dihasilkan

c. Menganalisis masalah dan menemukan teknik penyelesaian yang tepat.

d. Memilih pengetahuan untuk memecahkan masalah dan memilih teknik yang baik.

Untuk menyelesaikan proses pencarian terbaik, kami memilih node dengan menggunakan fungsi heuristik. Ditandai dengan node/simpul yang kita gunakan untuk menghasilkan aturan pengganti. Sebuah heuristik Fungsi membutuhkan strategi dalam memecahkan masalah dengan konsep selektif menggunakan jalur konsep yang memiliki nilai sebesar mungkin [2]. Pendapat [3]. Proses pencarian jalur terpendek antara 2 atau lebih node yang saling berhubungan. Menemukan jalur terpendek adalah masalah optimasi, biasanya formulir ini ditampilkan di bentuk grafik. jalur terpendek adalah bentuk grafik yang digunakan untuk menghitung rute terpendek, disebut juga graf berbobot. Istilah grafik ini diberikan untuk bobot atau nilai. Bobot sisi graf disebut jarak antar kota, waktu proses dalam pengiriman pesan, biaya ongkos kirim. [4]. Ada Ada 4 kriteria dalam menyelesaikan masalah pelayanan diantaranya :

1. Kelengkapan

2. Kompleksitas waktu

3. Kompleksitas ruang

4. Optimal

Menurut penelitian [5] metode yang dihasilkan berbeda dengan generasi dan metode pengujian lainnya. Lokasi perbedaan metode umpan balik dan prosedur dalam mencari solusi dengan menghilangkan ruang lebur. Jadi bisadapat disimpulkan bahwa pencairan tergantung pada bentuk aturan yang telah ditetapkan sehingga sehingga dapat kembali ke langkah awal. Hasil Riset [6] Bukit algoritma climbing dapat digunakan untuk menyelesaikan masalah kasus karena metode hill climbing merupakan bagian dari beberapa jenis dept-first-search yang dapat digunakan sebagai keputusan untuk mencari jalur dengan tujuan

Pemanfaatan Metode Hill Climbing Mencari Lintasan Terpendek Objek Wisata Menggunakan sistem Informasi (Sestri Novia Rizki) 
mengurangi biaya untuk mendapatkan tujuan, asalkan nilai heuristik menggunakan konsep nilai terkecil. Ada dua jenis Pendakian Bukit yang sedikit berbeda, yaitu Pendakian Bukit Sederhana dan Pendakian Bukit Terjal (Hill Climbing by memilih kemiringan yang paling curam). Mendaki bukit sederhana, awalnya keadaan selanjutnya adalah ditentukan dengan membandingkan keadaan saat ini dengan satu penerus. Proses perbandingan ini dimulai dari kiri. Jika pengganti baru ditemukan yang lebih baik dari keadaan saat ini, penerus akan menjadi negara berikutnya. Sementara di pendakian bukit pendakian paling curam di menentukan keadaan selanjutnya, keadaan saat ini secara langsung dibandingkan dengan semua penerus yang terdekat, sehingga state selanjutnya yang didapat adalah penerus terbaik dan dekat dengan hasil optimasi yang diharapkan. Selain itu, untuk mendaki bukit sederhana urutan operator penggunaan sangat berpengaruh pada solusi, sedangkan untuk tanjakan tercuram urutan pendakian bukit penggunaan operator tidak berpengaruh pada solusi. Dalam hal keuntungan dari sederhana mendaki bukit, efisiensi dalam hal memori. sedangkan pendakian bukit paling curam membutuhkan banyak memori dalam penyimpanannya. Algoritma pendakian bukit sederhana adalah sebagai berikut: (1) Evaluasi keadaan awal, jikakeadaan awal sama dengan tujuan, kemudian proses berhenti. Jika tidak sama dengan tujuan kemudian melanjutkan proses dengan menjadikan keadaan awal sebagai keadaan saat ini. (2) Lakukanlangkah-langkah berikut sampai solusi ditemukan atau sampai tidak ada operator baru yang dapat digunakan dalam keadaan saat ini: a. Temukan operator yang belum pernah digunakan dalam kondisi saat ini dan gunakan itu operator untuk membuat status baru. b. Evaluasi keadaan baru. Saya. Jika negara baru adalah tujuan, maka proses berhenti. ii. Jika keadaan baru bukanlah tujuan, tetapi keadaan baru adalah lebih baik dari keadaan saat ini, kemudian membuat keadaan baru keadaan saat ini. aku aku aku. Jika keadaan baru tidak lebih baik dari kondisi saat ini. TSP atau Travelling Salesman Problem dengan simple hill panjat tebing adalah suatu ruang keadaan yang membahas suatu kemungkinan yang terjadi pada suatu lintasan. Dasar Konsep yang digunakan adalah menggantikan posisi kota-kota yang saling berdekatan atau bersebelahan lainnya. Penggunaan heuristik adalah untuk menghitung panjang lintasan yang terjadi. Fungsinya dari operator adalah mengubah posisi 2 kota menjadi 1 jalur. Di bawah ini adalah penjelasan tentang kombinasi 4 kota dengan masing-masing kombinasi diantaranya:

1. Tukar Kota 1,2 (menukar urutan posisi kota ke-1 dengan kota ke-2).

2. Tukar Kota (menukar urutan posisi kota ke-2 dengan kota ke-3).

3. Tukar Kota (tukar urutan posisi kota ke-3 dengan kota ke-4).

4. Tukar Kota (menukar urutan posisi kota ke-4 dengan kota ke-1

5. Tukar Kota 2,4 (menukar urutan posisi kota ke-2 dengan kota ke-4).

6. Tukar Kota1,3 (menukar urutan posisi kota ke-1 dengan kota ke-3).

Contoh Kasus Panjang lintasan

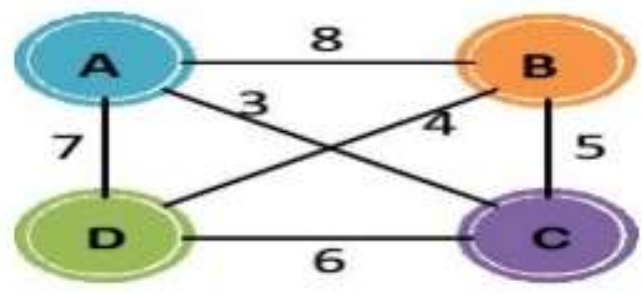

Gambar 1. panjang lintasan

Tahap penyelesaian kasus metode Simple Hill Climbing adalah :
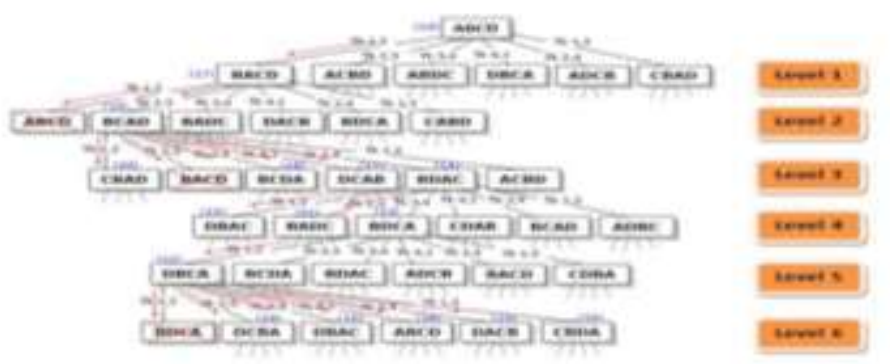

Pemanfaatan Metode Hill Climbing Mencari Lintasan Terpendek Objek Wisata Menggunakan sistem Informasi (Sestri Novia Rizki) 
Gambar 2. Tahapan Hill Climbing menggunakan 6 operator

Alur terkecil adalah bentuk jaringan dengan kerangka kerja yang memiliki simpul, titik terkemuka ke simpul lain dengan pilihan jalur yang akan dilalui. Tujuan utama dari yang terpendek ini path adalah untuk menemukan jalur terpendek ke titik akhir atau tujuan. Jika jalannya tidak diketahui, itu dapat menggunakan konsep koordinat dengan menghitung lintasan terkecil yang telah dilalui. [7] Di bidang teknologi informasi, itu membahas data, fakta dan berbagai macam informasi seperti gambar, angka, sinyal, analog teks dan lain-lain. Bagian lain dari data baru, fakta baru dan informasi baru dibutuhkan oleh pengguna atau user, bisa disebut informasi. Hasil Penelitian [8] menyatakan bahwa jalur terpendek diperoleh dengan menghitung banyak waktu tempuh berdasarkan jarak dari kota asal ke kota tujuan. Jika ada banyak alternatif jalur, semakin rumit cara untuk menemukan jalur terpendek. Tujuan menghitung jalur ini adalah untuk meminimalkan biaya dan waktu.

\section{METODELOGI PENELITIAN}

Metodelogi penelitian adalah sebuah proses penelitian yang dilakukan secara sistematis mulai dari awal sampai akhir sehingga mendapatkan hasil yang diharapkan. Konsep penelitian ini menggunakan perhitungan kualitatif[9]. Proses yang dilakukan untuk menyelesaikan kasus ini adalah:

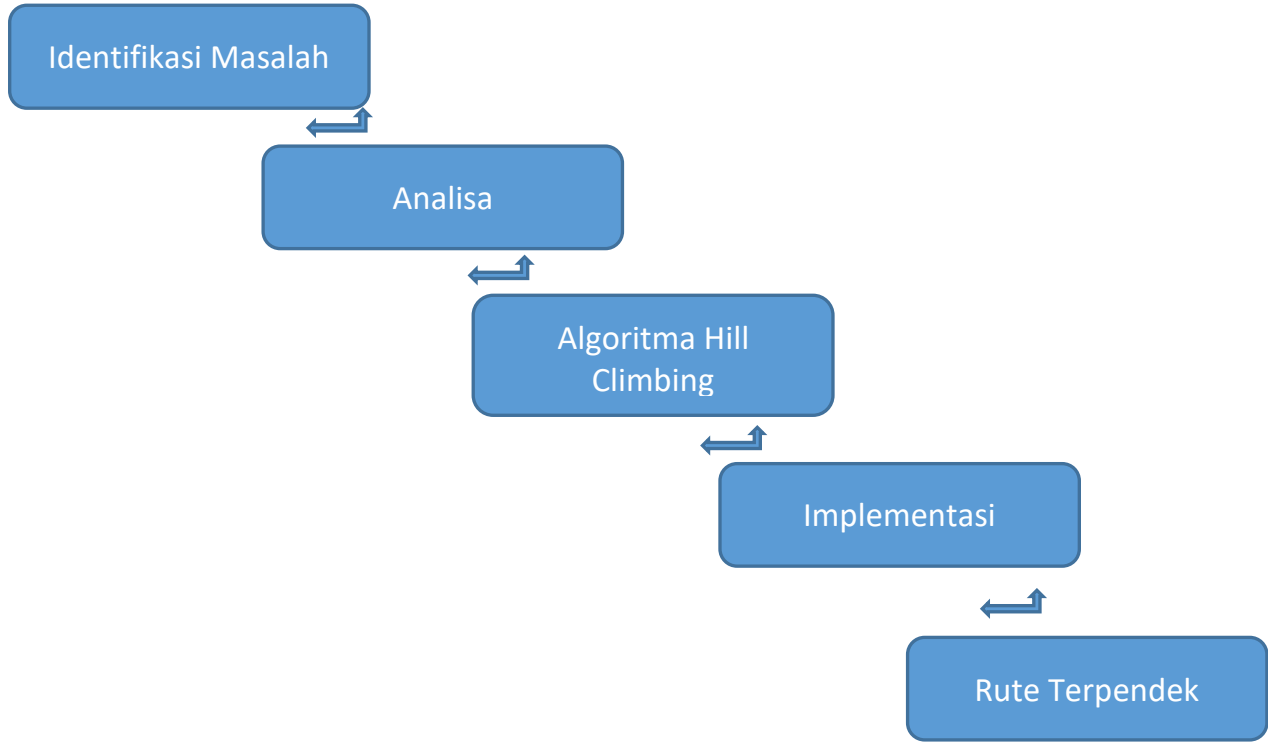

Gambar 3. Metodelogi Penelitian

\section{HASIL DAN PEMBAHASAN}

Implementasi metode Hill Climbing merupakan penentuan jalur terpendek untuk mengunjungi sebuah tempat wisata di kota Solok. Titik awal yang digunakan untuk mengunjungi Tempat wisata yaitu kota Solok. Ada 8 lokasi tempat wisata yang akan dikunjungi oleh wisatawan yaitu : Puncak Gagoan - Rumah Pohon Laing Park- Danau Singkarak - Puncak Gobah - Air terjun Kapalo Banda Koto Hilalang -Danau Talang- Danau diateh dan danau dibawah, - Kebun Teh Alahan Panjang. Hasil lokasi wisata bisa dilihat pada tabel dibawah ini :

Tabel 1. Objek Wisata Kota Solok

\section{Pemanfaatan Metode Hill Climbing Mencari Lintasan Terpendek Objek Wisata Menggunakan sistem Informasi (Sestri Novia Rizki)}


JURNAL ILMIAH ELEKTRONIKA DAN KOMPUTERp-ISSN: 1907-0012 e-ISSN : 2714-5417.

\begin{tabular}{|l|l|}
\hline No & Rute Perjalanan tempat Wisata \\
\hline 1 & Puncak Gagoan \\
\hline 2 & Rumah Pohon Laing Park \\
\hline 3 & Danau Singkarak \\
\hline 4 & Puncak Gobah \\
\hline 5 & Air terjun Kapalo Banda Koto Hilalang \\
\hline 6 & Danau Talang \\
\hline 7 & Danau diateh dan danau dibawah \\
\hline 8 & Kebun Teh Alahan Panjang \\
\hline & Total \\
\hline
\end{tabular}

Tabel 2. Hasil Rute

\begin{tabular}{|l|l|l|l|l|}
\hline No & Rute Perjalanan tempat Wisata & Jarak & Waktu (Jam) & Lama Kunjungan \\
\hline 1 & Puncak Gagoan & $25,3 \mathrm{~km}$ & 48 menit & 50 Menit \\
\hline 2 & Rumah Pohon Laing Park & $9,3 \mathrm{~km}$ & 17 menit & 50 Menit \\
\hline 3 & Danau Singkarak & $26,3 \mathrm{~km}$ & 43 menit & 50 Menit \\
\hline 4 & Puncak Gobah & $25,3 \mathrm{~km}$ & 48 menit & 50 Menit \\
\hline 5 & $\begin{array}{l}\text { Air terjun Kapalo Banda Koto } \\
\text { Hilalang }\end{array}$ & $14,5 \mathrm{~km}$ & 32 menit & 50 Menit \\
\hline 6 & Danau Talang & $20,7 \mathrm{~km}$ & 37 menit & 50 Menit \\
\hline 7 & Danau diateh dan danau dibawah & $40 \mathrm{~km}$ & 93 menit & 50 Menit \\
\hline 8 & Kebun Teh Alahan Panjang & 34,5 & 57 menit & 50 Menit \\
\hline & Total & $195,9 \mathrm{~km}$ & 375 menit & 360 menit \\
\hline
\end{tabular}

Dari gambar di atas dihasilkan beberapa rute yang dibutuhkan untuk mengililingi kota wisata yang ada dikota Solok, mulai dari rute terpendek hingga rute terpanjang. Total jarak yang ditembuh sebesar 195,9 km dengan waktu 375 menit atau 6 jam 15 menit dengan waktu kunjungan 360. Selain mencari jalur terpendek pengunjung wisata wisa melihat titik titik pusat yang akan dikunjungi dengan memilih beberapa wisata yang akan dikunjungi dengan milihat jarak dan waktu yang diperlukan. Untuk mendapatkan hasil diperlukan perhitungan manual dengan menggunakan kosnsep pencarian rute terpendek menggunakan simple hill climbing perhitungan manual dengan pengujian 8 Kota sehingga diperoleh:

$$
\begin{aligned}
= & \frac{8 !}{2 !(8-2) !} \\
\frac{8 !}{2 !(\mathrm{n}-2) !} & =28
\end{aligned}
$$

Bentuk Bagan Rute yang bisa digunakan dalam proses penggunaan operator dari hasil kombinasi yang bisa dilihat pada gambar dibawah ini : 


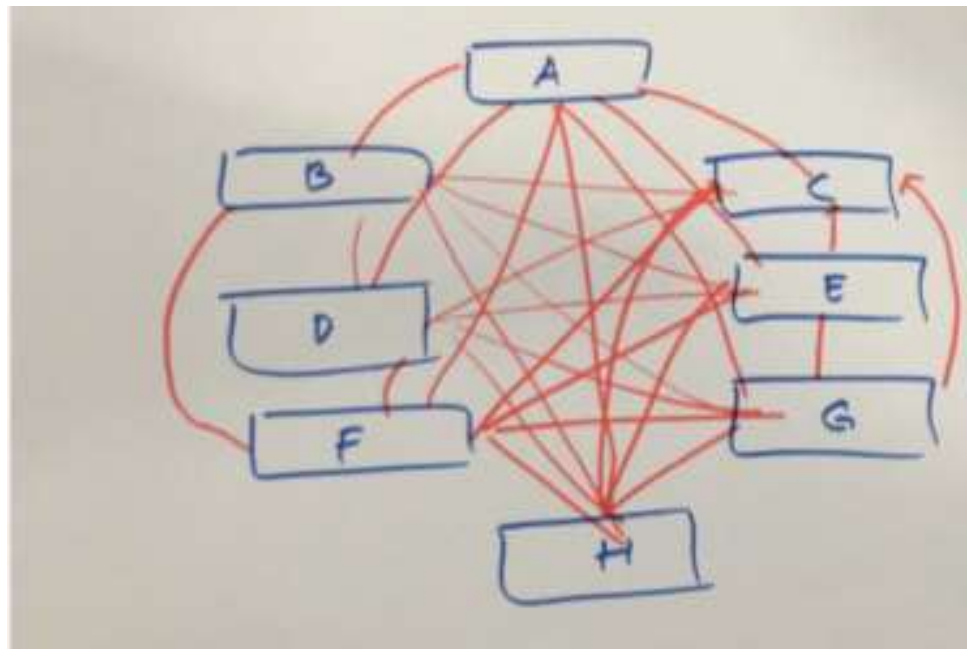

Gambar 4 . Hasil Kombinasi

Tabel 3. Hasil Kombinasi 8 Tempat Wisata

\begin{tabular}{|c|c|c|c|}
\hline No & Hasil Kombinasi & No & Hasil Kombinasi \\
\hline 1 & ABCDEFGH & 15 & CEFGHABD \\
\hline 2 & ACBDEFGH & 16 & CGHABDEF \\
\hline 3 & ADBCEFGH & 17 & CHABDEFG \\
\hline 4 & AEBCDFGH & 18 & CFGHABDE \\
\hline 5 & AFBCDEGH & 19 & DEFGHABC \\
\hline 6 & AGBCDEFH & 20 & DFGHABCE \\
\hline 7 & AHBCDEFG & 21 & DGHABCDE \\
\hline 8 & BCDEFGHA & 22 & DGABCEFH \\
\hline 9 & BDEFGHAB & 23 & EFGHABCD \\
\hline 10 & BEFGHACD & 24 & EGHABCDF \\
\hline 11 & BFGHACDE & 25 & EHABCDFG \\
\hline 12 & BGHACDEF & 26 & FGHABCDE \\
\hline 13 & BHABCDEF & 27 & FHABCDEG \\
\hline 14 & CDEFGHAB & 28 & GHABCDEF \\
\hline
\end{tabular}

Dari hasil kombinasi yang diperoleh sebanyak 28 maka langkah selanjutnya adalah mengambil 8 rute saja. Karena aturan dasarnya pencarian nilai terpendek hanya memiliki 1 tempat Start, 8 rute tersebut dapat dilihat dibawah ini :

Tabel 3. Hasil 8 Tempat Wisata

\begin{tabular}{|l|l|}
\hline 1 & ABCDEFGH \\
\hline 2 & ACBDEFGH \\
\hline 3 & ADBCEFGH \\
\hline 4 & AEBCDFGH \\
\hline 5 & AFBCDEGH \\
\hline 6 & AGBCDEFH \\
\hline
\end{tabular}

Pemanfaatan Metode Hill Climbing Mencari Lintasan Terpendek Objek Wisata Menggunakan sistem Informasi (Sestri Novia Rizki) 


\begin{tabular}{|l|l|}
\hline 7 & AHBCDEFG \\
\hline 8 & BCDEFGHA \\
\hline
\end{tabular}

Berdasarkan Pengolahan

data yang sudah dilakukan maka rute yang harus di tempuh pertama adalah rute Terpendek yaitu Rumah Pohon Laing Park-Air terjun Kapalo Banda Koto Hilalang-Danau Talang-Puncak Gagoan- Puncak Gobah-Danau Singkarak Kebun teh alahan panjang dan lokasi terakhir adalah Danau Danau Ateh dan danau dibawah dengan total jarak 195,9 km waktu 375 menit dan lama kunjungan 360 menit.

\section{KESIMPULAN DAN SARAN}

Hasil penelitian penentuan rute terpendek menggunakan sistim informasi grafis dan algoritma simple hill climbing dapat disimpulkan sebagai berikut:

1. Implementasi sistim informasi menggunakan sistim jalur terpendek dapat dijadikan sebagai media informasi bagi pengunjung serta menghasilkan manfaat bagi wisatawan yang ingin mengunjungi kota Solok

2. Metode Algoritma Simple Hill Climbing Mempermudah mencari lintasan terpendek menggunakan atribut dalam subuah lokasi wisata.

3. Membantu para pengunjung untuk mengetahui sebuah rute wisata karena kurangnya informasi dan bisa menghemat waktu dan biaya perjalanan.

4. Hasil penelitian ini bisa dikembangkan lagi dengan menggunakan Aplikasi terbaru, sehingga aplikasi tersebut bisa menunjuk ke arah mana rute yang paling dekat yang dikunjungi terlebih dahulu, sehingga tidak terjadi perulangan perjalanan dengan melewati jalur yang sama.

\section{DAFTAR PUSTAKA}

[1] Aida, S. Aries, P. D. (2017). Penjadwalan Kuliah Menggunakan Algoritma Hill Climbing. Prosiding Seminar Nasional Informatika dan Sistem Informasi, 1, 98-105.

[2] Dangkua, E.V., Gunawan, V., \& Adi, K. (2015). Aplikasi Mendaki Bukit Metode Dalam Sistem Informasi Geografis Untuk Menemukan Jalur Terpendek. Jurnal dari Sistem Informasi Bisnis,5(1).https://doi.org/10.21456/vol5iss1pp19-25.

[3] Nurdin, N., \& Harahap, S. (2016). Implementasi Algoritma Pendakian Bukit Dan Algoritma A* Dalam Melengkapi Suku Kata Dasar Dengan Game Morning Star Pola. Jurnal Informatika, 10(2). https://doi.org/10.26555/jifo.v10i2.a5064.

[4] Abrori, M., \& Setiyani, R.N. (2015). Implementasi Best-First Search (BeFS) Algoritma dalam Menyelesaikan Travelling Salesman Problem (TSP) (Studi Kasus: Travel in Kota Yogyakarta). Jurnal Fourier, 4(2), 93. https://doi.org/10.14421/fourier.2015.42.93-111.

[5] Juniansyah, A., \& Masterjon, M. (2016). Aplikasi Penentuan Rute Pendek Untuk Bagian Pemasaran Produk Roti Tenaga Surya Dengan Metode Pencarian Pertama Terbaik. Jurnal Infotama Media, 12(1). https://doi.org/10.37676/jmi.v12i1.270.

[6] Juniansyah, A., \& Mesterjon. (2016). Aplikasi Penentuan Rute Terpendek Untuk Departemen pemasaran. Media Infotama, 12(1), 31-40.

[7] Ilwaru, V. Y. I., Sumah, T., Lesnussa, Y. A., \& Leleury, Z. A. (2017). Perbandingan Algoritma Hill Climbing Dan Algoritma Ant Colony Dalam Menentukan Optimum Rute. Barekeng: Jurnal Ilmu Terapan dan Matematika, 11(2), 139-150. https://doi.org/10.30598/barekengvol11iss2pp139-150.

[8] Sugiyono. (2012). Metode Penelitian Kuantitatif, Kualitatif dan R\&D. Bandung : ALFABETA.

[9] Suyanto. (2011). Kecerdasan Buatan (edisi ke-2). Bandung: Informasi. 